\title{
Uji Fisikokimia dan Uji Iritasi Sabun Antiseptik Kulit Daun Aloe vera (L.)
}

\section{Burm. f}

Penulis

Afiliasi

\author{
Eka Kartika Untari , dan Robiyanto
}

Program Studi Farmasi, Fakultas Kedokteran, Universitas Tanjungpura, Indonesia

\section{Kata Kunci \\ - Aloe vera \\ - Sabun antiseptik \\ - Uji iritasi}

Diterima 5 September 2017

Direvisi 9 Januari 2018

Disetujui 3 Agustus 2018

* Penulis Koresponding Eka Kartika Untari Jl. Profesor Dokter H. Hadari Nawawi, Bansir Laut, Pontianak Tenggara, Pontianak, Kalimantan, 78121 ekakartika@pharm.untan.ac.id

\section{ABSTRAK}

Tanaman lidah buaya merupakan tanaman khas Kalimantan Barat yang memiliki sifat antibakteri, sehingga pada penelitian ini menjadi bahan baku utama pada sediaan sabun cair. Pada penelitian sebelumnya sediaan sabun cair antiseptik lidah buaya ini berpotensi sebagai antiseptik pada penderita ulkus diabetik, oleh karena itu diperlukan uji iritasi sebelum diberikan kepada penderita. Tujuan penelitian adalah untuk menguji sifat fisikokimia dan menentukan ada atau tidaknya efek iritasi akibat pemberian sabun cair lidah buaya pada partisipan sehat. Desain penelitian untuk uji iritasi adalah penelitian eksperimental one group pre-test and post test design yang melibatkan 12 orang partisipan. Formulasi sabun cair terdiri dari infus kulit daun lidah buaya, minyak jarak, KOH, HPMC, asam stearat, gliserin, BHT, dan akuades. Sabun cair diujikan sifat fisikokimia sebelum dilakukan uji iritasi. Uji iritasi menggunakan metode open patch test dengan mengoleskan satu kali sehari sebanyak $2 \mathrm{~mL}$ sabun cair ke daerah tengkuk selama 3 hari berturut-turut. Pengamatan efek iritasi pada 30 menit, 1 hari dan 3 hari setelah pengolesan. Hasil uji iritasi yang diperoleh bahwa tidak terdapat gejala iritasi berupa rasa gatal, kemerahan, kulit bengkak, dan rasa perih pada semua partisipan. Berdasarkan hasil uji tersebut dapat disimpulkan bahwa sabun cair lidah buaya tidak memiliki efek iritasi pada kulit partisipan sehat.

\section{PENDAHULUAN}

Lidah buaya telah digunakan oleh masyarakat menjadi berbagai olahan baik makanan maupun obat-obatan namun bagian kulit daun lidah buaya menjadi limbah dari produksi lidah buaya tersebut. Kulit daun lidah buaya dapat dimanfaatkan sebagai sumber senyawa aktif untuk menghambat bakteri selain itu mengurangi limbah kulit daun lidah buaya dari produksi lidah buaya serta dilakukan pemanfaatan limbah kulit daun buaya yang selama belum dimanfaatkan. Kandungan zat aktif lidah buaya yang sudah teridentifikasi antara lain saponin, sterol, acemannan, antrakuinon (Rahayu 2006). Penelitian yang telah dilakukan sebelumnya menunjukkan bahwa ekstrak lidah 
buaya dalam bentuk sediaan gel terbukti efektif terhadap bakteri Gram positif (Staphylococcus aureus, Staphylococcus epidermidis, Staphylococcus pyrogenes) dan Gram negatif (Pseudomonas aeruginosa) (Sari 2016).

Sabun terbuat dari garam alkali asam lemak dan dihasilkan menurut reaksi asam basa. Proses pembuatan sabun disebut saponifikasi. Sabun cair didefinisikan sebagai sediaan pembersih kulit berbentuk cair yang dibuat dari bahan dasar sabun atau deterjen dengan penambahan bahan lain yang diijinkan dan digunakan tanpa menimbulkan iritasi pada kulit. Sabun mandi didefinisikan sebagai sabun natrium yang pada umumnya ditambahkan zat pewangi atau antiseptik dan digunakan untuk membersihkan tubuh dan tidak membahayakan kesehatan (Wasitaatmadja 1997).

Iritasi adalah suatu reaksi kulit terhadap zat kimia misalnya alkali kuat, asam kuat, pelarut dan detergen. Beratnya bermacam-macam dari hyperemia, edema, dan vesikulasi sampai pemborokan. Iritasi primer terjadi ditempat kontak dan umumnya pada sentuhan pertama. Pengujian iritasi dapat dilakukan dengan menggunakan Uji Tempel (Patch Test) (Basketter et al. 2004). Uji tempel adalah uji iritasi dan kepekaan kulit yang dilakukan dengan cara mengoleskan sediaan uji pada kulit panel normal manusia dengan maksud untuk mengetahui apakah sediaan tersebut dapat menimbulkan iritasi pada kulit atau tidak. Iritasi umumnya akan segera menimbulkan reaksi kulit sesaat setelah pelekatan pada kulit, iritasi demikian disebut iritasi primer. Tetapi jika iritasi tersebut timbul beberapa jam setelah pelekatannya pada kulit, iritasi ini disebut iritasi sekunder. Tanda-tanda reaksi kulit yang ditimbulkan yaitu hiperemia, eritema, edema atau vesikula kulit. Reaksi kulit yang demikian bersifat lokal pada daerah kulit yang rusak saja (Schmitt WH, 1996). Reaksi kulit akibat iritan primer terjadi antara beberapa menit hingga satu jam setelah pelekatan (Sunsmart 1998).

Potensi Aloe vera sebagai antibakteri dikembangkan menjadi sediaan sabun cair antiseptik yang memiliki potensi antibakteri pada Staphyllococcus aureus, Staphylococcus epidermidis, Bacillus subtilis, Bacilus cereus, Salmonella typhimurium, Proteus mirabilis, Pseudomonas aeruginosa, dan Escherichia coli. Bakteri ini merupakan patogen yang ditemukan pada hasil swab penderita ulkus diabetik (Sari et al. 2016). Beberapa tanaman tradisional termasuk Aloe Vera dilaporkan menimbulkan reaksi alergi (Ernst 2008). Oleh karena itu sediaan sabun yang mengadung infus kulit daun lidah buaya pada penelitian ini dilakukan uji iritasi pada partisipan sehat. Ada atau tidaknya kejadian iritasi kepada partisipan sehat dapat membuktikan bahwa sediaan tersebut selanjutnya aman digunakan dalam penanganan ulkus diabetik.

\section{METODE}

Desain penelitian ini adalah pre eksperimental dengan desain one group pretest and postest. Kulit daun lidah buaya diolah menjadi infus dan digunakan sebagai bahan utama sabun cair. Sabun cair diuji iritasi kepada 12 subjek sehat. Penelitian ini telah diterima oleh komisi etik Fakultas Kedokteran Universitas Tanjungpura dengan nomor 6728/UN22.9/DT/2016 tanggal 23 September 2016.

Alat yang digunakan pada penelitian ini antara lain pisau, wadah plastik, lemari pendingin, blender, sendok tanduk, timbangan analitik, sendok stainless, labu ukur $25 \mathrm{~mL}$ dan $50 \mathrm{~mL}$, gelas ukur $25 \mathrm{~mL}$ dan $50 \mathrm{~mL}$, erlenmeyer $250 \mathrm{ml}$, beaker glass, viskometer stormer, tip dan mikropipet, $\mathrm{pH}$ meter, mortar dan stamper, batu didih, dan kamera telepon genggam. Bahan yang digunakan phenolphthalein, alkohol 96\%, larutan $\mathrm{HCl}$ $0.1 \mathrm{~N}$ dan $\mathrm{KOH} 0.1 \mathrm{~N}$, minyak jarak, $\mathrm{KOH} 10 \%, \mathrm{HPMC}$, asam stearat, gliserin, $\mathrm{BHT}$, akuades, tisu kering, kapas, dan alcohol swab.

Tanaman yang digunakan pada penelitian ini adalah limbah kulit daun lidah buaya. Sampel diambil dari usaha pembuatan olahan lidah buaya. Sampel yang diambil dalam keadaan bebas daging daun lidah buaya dan tidak mengalami pembusukan. Identifikasi tanaman yang digunakan pada penelitian ini dilakukan di Laboratorium Biologi Fakultas Matematika dan Ilmu Pengetahuan Alam (FMIPA) Universitas Tanjungpura. Limbah kulit daun lidah buaya dibersihkan dari daging daun (gel) yang masih menempel kemudian dihaluskan dengan cara diblender dan ditimbang 15 gram untuk diinfus dengan $100 \mathrm{~mL}$ dengan akuades selama 15 menit sambil diaduk. Setelah 15 menit diambil airnya untuk digunakan dalam formulasi sediaan.

Bahan ditimbang dengan seksama. Masukan minyak jarak kedalam gelas kimia, kemudian tambahkan $\mathrm{KOH}$ sedikit demi sedikit sambil terus dipanaskan pada suhu $60-70^{\circ} \mathrm{C}$ hingga terbentuk pasta, lalu dimasukkan asam stearat yang telah dilelehkan diatas penangas air diaduk hingga homogen, kemudian masukkan BHT dan HPMC yang telah dikembangkan dalam aquadest 
panas, diaduk hingga homogen, tambahkan gliserin aduk hingga homogen, masukan minyak atsiri dan aduk hingga homogen. Sabun cair ditambahkan aquadest hingga $100 \mathrm{~mL}$ lalu diaduk hingga homogen dan masukan kedalam wadah bersih yang telah disiapkan Formulasi sabun mandi cair terdiri dari infus kulit daun lidah buaya, minyak jarak, $\mathrm{KOH}, \mathrm{HPMC}$, asam stearat, gliserin, BHT, dan akuades.

Pengujian organoleptik dan sifat fisikokimia sabun mandi cair (SNI 1994) dilakukan sebelum uji klinis. Uji fisikokimia yang dilakukan terdiri dari uji $\mathrm{pH}$, kadar asam lemak dan alkali bebas, viskositas, dan bobot jenis. Pengujian $\mathrm{pH}$ dilakukan dengan menggunakan $\mathrm{pH}$ meter. Pada uji asam lemak dan alkali bebas, sebanyak $5 \mathrm{~g}$ sampel dimasukkan ke dalam erlenmeyer $250 \mathrm{ml}$. Tambahkan $100 \mathrm{ml}$ alkohol netral, batu didih dan 10 tetes phenolphtalein. Panaskan diatas penangas air memakai pendingin tegak selama 30 menit mendidih. Bila larutan berwarna merah berarti mengandung alkali bebas, kemudian dititar dengan larutan $\mathrm{HCl} 0.1 \mathrm{~N}$ dalam alkohol sampai warna merah tepat hilang, akan tetapi bila larutan tidak bersifat alkalis (tidak berwarna merah) berarti mengandung asam lemak bebas, kemudian dititar dengan larutan $\mathrm{KOH} 0,1 \mathrm{~N}$ dalam alkohol sampai timbul warna merah. Pengujian bobot jenis menggunakan piknometer.

Kriteria inklusi untuk partisipan untuk uji iritasi adalah sehat jasmani dan rohani, berusia di atas 18 tahun, tidak memliki riwayat alergi kulit sebelumnya, tidak dalam keadaan sakit (demam) saat pengujian berlangsung. Tes kesehatan dilakukan oleh seorang tenaga medis dokter (medical officer). Uji iritasi terhadap kulit partisipan dilakukan dengan cara uji tempel terbuka (patch test). Uji tempel terbuka dilakukan dengan mengoleskan sediaan pada lengan bawah bagian dalam yang dibuat pada lokasi lekatan dengan luas tertentu $(2,5 \times 2,5 \mathrm{~cm})$, dibiarkan terbuka dan diamati apa yang terjadi. Uji ini dilakukan sebanyak 2 kali sehari (pagi dan sore hari) selama 3 hari berturutturut. Reaksi iritasi positif ditandai oleh adanya kemerahan, gatal-gatal, atau bengkak pada kulit lengan bawah bagian dalam yang diberi perlakuan.

Data yang diperoleh berupa data kuantitatif dan data kualitatif. Data kuantitatif terdiri nilai $\mathrm{pH}$ sediaan sabun, nilai kadar asam lemak bebas, nilai bobot jenis, tinggi busa dan nilai viskositas. Sedangkan data kualitatif berupa hasil uji organoleptik dan uji iritasi sediaan sabun mandi cair. Semua data dianalisa dengan analisa deskriptif.

\section{HASIL DAN PEMBAHASAN}

Sabun mandi yang dihasilkan diuji sifat fisikokimianya berdasarkan Standar Nasional Indonesia (SNI) 1994 yang bertujuan untuk melihat sifat fisik dan kimia dari sediaan yang dibuat serta berfungsi untuk melihat bahwa mutu suatu sediaan yang dihasilkan aman dan tidak berbahaya saat digunakan. Analisis sifat fisiko kimia sabun juga penting dalam menentukan formula sabun terbaik yang sesuai dengan persyaratan SNI. Uji fisik yang dilakukan meliputi pengamatan organoleptis, bobot jenis, tinggi busa, dan viskositas. Sedangkan uji kimia yang dilakukan meliputi pengukuran nilai $\mathrm{pH}$ sabun dan asam lemak bebas/alkali bebas. Hasil evaluasi tersebut dapat dilihat pada Tabel 1.

Pengujian secara organoleptis bertujuan untuk mengetahui penampilan fisik sediaan sabun cair kulit daun lidah buaya. Sabun cair kulit daun lidah buaya yang dihasilkan berbentuk cairan kental dan homogen, berwarna putih agak kekuningan dan berbau khas tanaman Aloe Vera. Hasil pengamatan organoleptis sabun cair pada penelitian ini telah sesuai dengan standar yang telah ditetapkan SNI 1996. Busa merupakan salah satu parameter yang paling penting dalam menentukan mutu produk-produk deterjen terutama sabun mandi. Tujuan pengujian busa pada penelitian ini adalah untuk melihat daya busa dari sabun mandi cair. Busa yang stabil cukup lama lebih diinginkan karena busa dapat membantu membersihkan tubuh (Pradipto 2009). Tinggi busa diukur setiap 5 menit selama 15 menit berturut-turut untuk mengamati konsistensi keberadaan busa. Karakteristik busa sabun dipengaruhi oleh beberapa faktor yaitu adanya bahan surfaktan, penstabil busa dan bahan-bahan penyusun sabun cair lainnya (Amin, 2006). Sabun dapat memberikan busa yang berlebih dengan mengkombinasikan minyak jarak dengan minyak kelapa. Minyak kelapa merupakan minyak yang memiliki kandungan asam lemak jenuh yang tinggi karena mengandung asam laurat yang paling dominan (Srivasta 1982). Asam laurat inilah yang memberikan sifat pembusaan yang baik dalam produk sabun (Srivasta 1982). Hasil pengujian tinggi busa sediaan (Tabel 1) tidak berubah hingga 15 menit pengamatan, sehingga busa yang terbentuk pada sediaan dapat dianggap stabil.

Derajat keasaman $(\mathrm{pH})$ merupakan parameter penting pada produk kosmetik, karena $\mathrm{pH}$ dapat mempengaruhi daya absorpsi kulit. pH merupakan nilai yang menunjukkan derajat keasaman suatu bahan. 
Tabel 1. Hasil Evaluasi Fisikokimia Sabun Mandi Cair Daun Lidah Buaya

\begin{tabular}{lcc}
\multicolumn{1}{c}{ Pengamatan } & Hasil & Standar SNI \\
\hline Tekstur & $\begin{array}{c}\text { Cairan homogen } \\
\text { Putih Kekuningan } \\
\text { Warna }\end{array}$ & $\begin{array}{c}\text { Cairan homogen } \\
\text { Khas Aloe Vera }\end{array}$ \\
Bau & & Khas \\
Tinggi Busa: & $100 \%$ & - \\
$\quad 5$ menit & $100 \%$ & \\
10 menit & $100 \%$ & $8-11$ \\
15 menit & & \\
pH: & 8 & \\
Hari 0 & 8.9 & $<2.5 \%$ \\
Hari 7 & 9.4 & \\
Hari 14 & $0.197 \%$ & Maksimal $0.1 \%$ \\
Kadar Asam Lemak Bebas & $0.24 \%$ & \\
Kadar Alkali Bebas & & \\
\hline
\end{tabular}

Derajat keasaman atau $\mathrm{pH}$ merupakan suatu proses mengukur tingkat keasaman dari suatu substansi dalam larutan (Cavitch 1997). Pengukuran nilai pH berfungsi untuk mengetahui sabun yang dihasilkan bersifat asam atau basa. Hasil pengukuran pH sabun mandi cair pada penelitian ini dibandingkan dengan standar yang telah ditetapkan SNI 1996, yaitu 8-11 (SNI 1996; Wasitaatmadja 1997). Secara umum, produk sabun cair memiliki $\mathrm{pH}$ yang cenderung basa, hal ini dikarenakan bahan dasar penyusun sabun cair tersebut yaitu $\mathrm{KOH}$ yang bersifat basa kuat. Nilai $\mathrm{pH}$ sabun yang dihasilkan telah memenuhi persyaratan SNI. Nilai pH sabun yang terlalu rendah dapat menyebabkan peningkatan daya absorbsi sabun pada kulit sehingga dapat menyebabkan iritasi pada kulit, sedangkan nilai $\mathrm{pH}$ yang terlalu tinggi juga dapat menyebabkan iritasi pada kulit (Hernani 2010).

Asam lemak bebas adalah asam lemak yang berada dalam sabun tetapi yang tidak terikat sebagai senyawa natrium ataupun senyawa trigliserida (lemak mineral). Tujuan pemeriksaan asam lemak bebas yaitu untuk menentukan kualitas atau karakteristik sabun yang dihasilkan. Pemeriksaan asam lemak bebas di lakukan bila pada pemeriksaan alkali bebas ternyata tidak terjadi warna merah dari indikator phenolphthalein (PP) setelah pendidihan dalam alkohol netral (SNI 1994).

Hasil pengukuran asam lemak bebas sabun mandi cair pada penelitian ini adalah $0.197 \%$. Hasil pengukuran asam lemak bebas dibandingkan dengan standar yang telah ditetapkan SNI 1994. Berdasarkan SNI 1994 maksimal kadar asam lemak bebas yang terdapat dalam sabun yaitu <2.5\%, maka pada penelitian ini terlihat bahwa kadar asam lemak bebas sabun mandi cair memenuhi standar.

Alkali bebas merupakan alkali yang terdapat dalam sabun yang tidak terikat selama proses penyabunan (SNI 1994). Kadar alkali bebas yang diperoleh pada sabun mandi cair adalah $0.24 \%$. Sabun cair mengandung alkali bebas karena larutan uji berwarna merah muda dengan indikator PP sehingga dititrasi dengan $\mathrm{HCl}$ hingga warna merah muda tepat hilang.

Hasil menunjukkan bahwa sabun mandi yang dibuat pada penelitian ini tidak memenuhi standar SNI karena melebihi kadar alkali bebas yang diperbolehkan. Rentang kadar alkali bebas menurut SNI yang diperbolehkan adalah tidak lebih dari $0.1 \%$. Tingginya kadar alkali yang diperoleh disebabkan penambahan kadar alkali yang berlebihan pada saat proses penyabunan (Hernani et al. 2010).

Pengujian efek iritasi sediaan sabun cair dari daun lidah buaya merupakan salah satu tahapan dari penelitian yang akan menentukan potensi selanjutnya sabun cair limbah tanaman endemik daun lidah buaya (Aloe barbadensis Mill.) sebagai agen terapi multi-drug resistant pada infeksi ulkus diabetik. Pada waktu sebelumnya pengujian sifat iritatif suatu bahan menggunakan rabbit skin test, namun prosedur alternatif lainnya yaitu menggunakan partisipan manusia dan memenuhi standar etik diperbolehkan (Basketter et al. 2004).

Uji iritasi sabun kulit daun lidah buaya mengikuti prosedur skin patch test (PT). PT adalah prosedur uji in vivo yang penting untuk mengkonfirmasi kondisi alergi

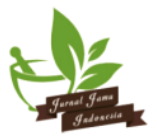


T-limfosit dan atau sensitisasi pada subjek yang disebabkan dermatitis kontak alergi, eksim atopik, serta alergi makanan dan obat-obatan. Uji tersebut untuk membuktikan kejadian sensitisasi sehingga dapat menentukan etiologi alergi terutama reaksi yang dicurigai adalah tipe IV. Kejadian alergi pada prosedur ini hanya di area yang sempit dan reaksi berlangsung hingga 20 menit setelah aplikasi (Wilkinson et al. 1997; Tanno et al. 2016).

Pengujian dilakukan langsung ke kulit tubuh manusia dikarenakan diharapkan sediaan sabun ini dapat langsung diaplikasikan kepada manusia jika sudah terbukti tidak memiliki efek iritasi pada kulit manusia. Pengolesan dilakukan 2 kali sehari, yaitu jam 07.00 pagi dan jam 16.00 sore selama 3 hari berturutturut yaitu tanggal 14-16 Oktober 2016 (Gambar 1).
Alasan pemilihan waktu ini adalah karena disesuaikan dengan waktu mandi lazim masyarakat pada umumnya yaitu tiap pagi dan sore hari. Metode uji iritasi adalah open patch test (uji tempel terbuka) olesan sabun cair dibiarkan terbuka selama 30 menit serta diamati ada atau tidaknya gejala iritasi berupa kemerahan, rasa gatal/alergi, bengkak, dan rasa perih di bagian kulit yang dioleskan sediaan sabun cair tersebut.

Menurut klasifikasi EC Annex to Commission Directive (1992), sediaan sabun cair Aloe vera tidak tergolong yang dapat mengiritasi kulit, karena setelah lebih dari 4 jam paparan sabun tidak menimbulkan tanda dan gejala iritasi maupun korosif pada kulit. Timbulnya kejadian alergi (hasil positif) atau hasil yang negatif bergantung pada substansi zat uji dan riwayat dermatitis kontak partisipan. Dermatitis kontak atau

Tabel 3. Hasil pengamatan uji iritasi selama 3 hari berturut-turut pada daerah tengkuk beberapa partisipan

\begin{tabular}{ccc} 
Tanggal Pengujian & Sebelum Pengujian & Setelah Pengujian \\
\hline
\end{tabular}

14 Oktober 2016

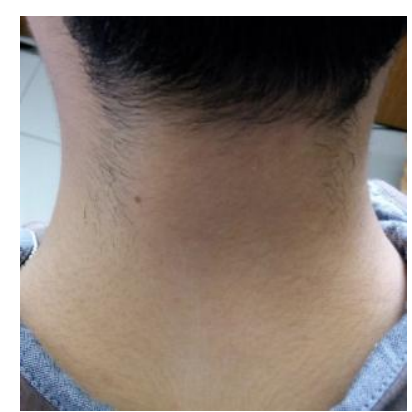

15 Oktober 2016

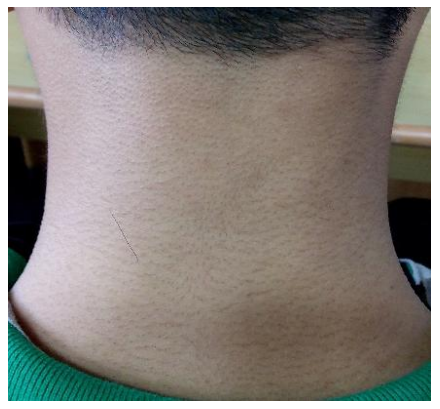

16 Oktober 2016
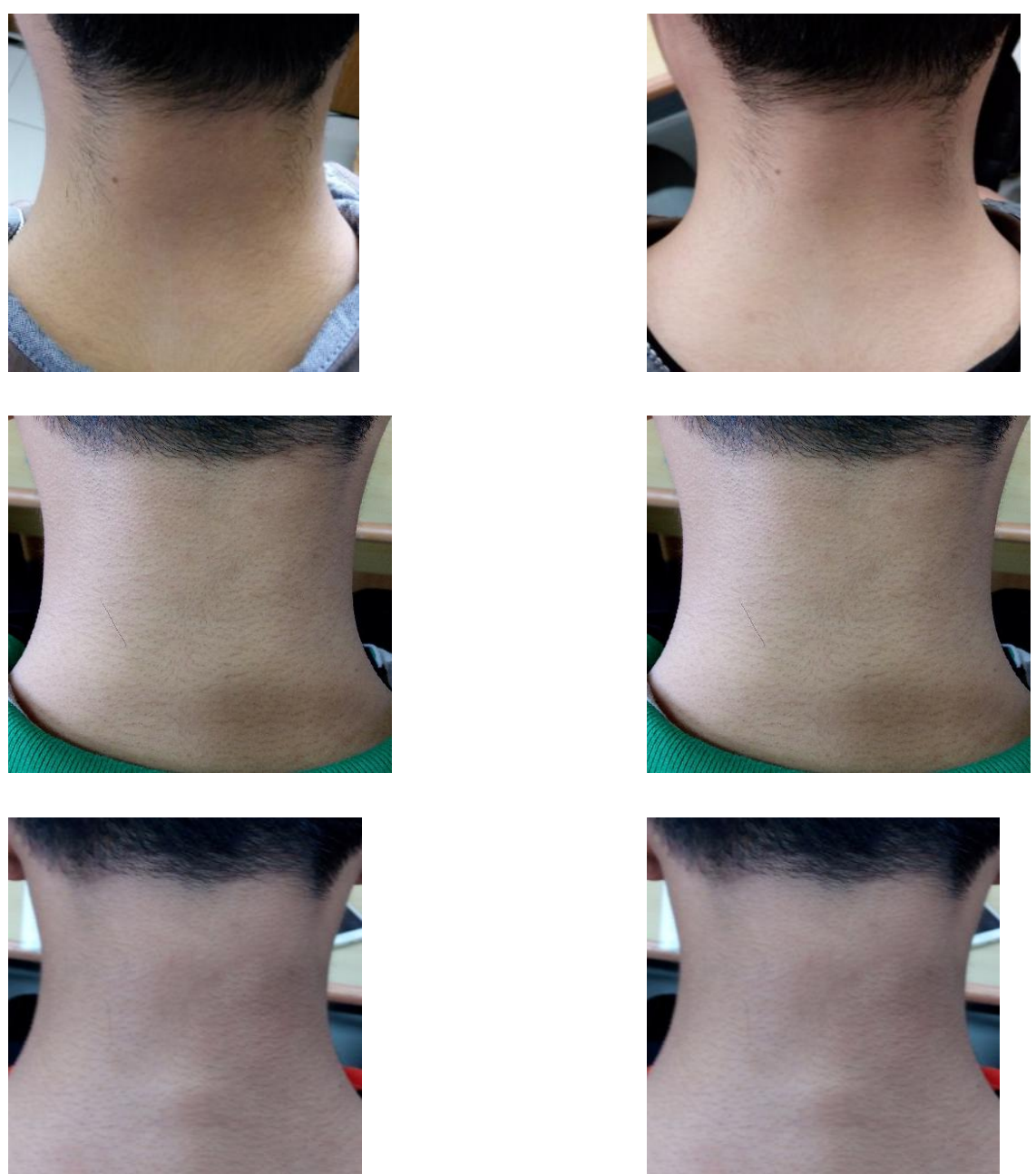
Tabel 2. Hasil pengamatan uji iritasi sediaan sabun cair pada 12 partisipan

\begin{tabular}{lccc}
\multicolumn{1}{c}{ Jenis Iritasi } & \multicolumn{3}{c}{ Tanggal Pengujian } \\
\cline { 2 - 4 } & 14-Okt & 15-Okt & 16-Okt \\
\hline 1. Rasa gatal & $\mathrm{X}$ & $\mathrm{X}$ & $\mathrm{X}$ \\
2. Kemerahan & $\mathrm{X}$ & $\mathrm{X}$ & $\mathrm{X}$ \\
3. Kulit bengkak & $\mathrm{X}$ & $\mathrm{X}$ & $\mathrm{X}$ \\
4. Rasa perih & $\mathrm{X}$ & $\mathrm{X}$ & $\mathrm{X}$ \\
\hline
\end{tabular}

Ket: $\mathrm{X}=$ tidak ditemui jenis iritasi pada 12 partisipan

eksim kontak adalah kondisi kulit yang diakibatkan reaksi inflamasi oleh suatu alergen. Alergen dapat menembus barrier kulit dan membentuk kompleks dengan protein melaui haptennya. Ikatan inilah yang akan berinteraksi dengan system imun terkait mukosa pada kulit (SALT/ Skin-Associated Lymphoid Tissue), dan mediator lainnya yang berperan dalam reaksi inflamasi (De Benedetto et al. 2012; Lazzarini et al. 2013). Kriteria pengamatan pengujian open patch meliputi ada atau tidaknya reaksi alergi meliputi eritema, udem, dan timbulnya vesikular (Wilkinson et al. 1997).

Berdasarkan Tabel 2. terlihat bahwa selama 3 hari pengujian, peneliti memperoleh hasil berdasarkan pengamatan bahwa 30 menit setelah sediaan sabun cair yang dujikan kepada 12 sukerelawan tidak menimbulkan efek iritasi pada kulit, khususnya bagian tengkuk leher. Hal ini terbukti dengan tidak ada seorangpun dari 12 partisipan yang merasakan efek alergi pada kulit yang diolesi sabun cair. Pengamatan hingga 1 bulan setelah pengujian (pertengahan November) juga menunjukkan hasil bahwa tidak ada efek iritasi lanjutan dari sediaan sabun cair pada daerah tengkuk dari leher ke-12 subyek uji. Penanda reaksi inflamasi pada pengujian PT pada penelitian ini melalui kriteria munculnya gejala rasa gatal, kemerahan, kulit bengkak, dan rasa perih. Dengan demikian, sediaan ini bersifat aman jika digunakan sebagai sabun cair pada kulit manusia.

\section{SIMPULAN}

Sediaan sabun cair antiseptic Aloe vera dengan komposisi terdiri dari infus kulit daun lidah buaya, minyak jarak, $\mathrm{KOH}, \mathrm{HPMC}$, asam stearat, gliserin, $\mathrm{BHT}$, dan akuades tidak menimbulkan iritasi pada kulit partisipan setelah dioleskan pada daerah tengkuk.

\section{UCAPAN TERIMA KASIH}

Peneliti mengucapkan terimakasih kepada Fakultas Kedokteran Universitas Tanjungpura dalam memberikan hibah penelitian DIPA serta dr. Andriani, M.Biomed selaku medical officer yang turut mengawasi jalannya uji klinis (uji iritasi) sabun cair Aloe vera.

\section{DAFTAR PUSTAKA}

Amin H. 2006, Kajian Penggunaan Kitosan Sebagai Pengisi dalam Pembuatan Sabun Transparan (skripsi). Bogor (ID): Program Studi Teknologi Hasil Perikanan. Fakultas Perikanan dan IImu Kelautan. Institut Pertanian Bogor.

Basketter DA, Chamberlain M, Griffiths HA, York M. 1997. The classification of skin irritants by human patch test. Food Chemistry Toxicology. 35: 845852.

Cavitch SM. 1997. The Soapmaker's Companion A Comprehensive Guide With Recipes, Techniques \& Know How. North Adams: Storey Books.

De Benedetto A, Kubo A, Beck LA. 2012. Skin Barrier Disruption: a Requirement for Allergen Sensitization. Journal of Investigative Dermatology. 132: 949-963

EC Annex to Commission Directive 92/69/EEC of 31 July 1992 adapting to technical progress for the seventeenth time Council Directive 67/548/EEC on the approximation of laws, regulations and administrative provisions relating to the classification, packaging and labelling of dangerous substances. Off J Eur Communities: L383A: 35.

Ernst E. 2008. Adverse effects of herbal drugs in dermatology. British Journal of Dermatology. 143(5): 923-929.

Hernani, Bunasor TK, Fitriati. 2010. Formula Sabun Transparan Antijamur Dengan Bahan Aktif Ekstrak Lengkuas (Alpinia galanga L.Swartz). Bogor: Jurusan Teknologi Industri Pertanian, Fakultas

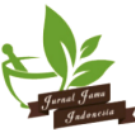


Teknologi Institut Pertanian Bogor Kampus IPB Darmaga. Buletin Penelitian Tanaman Rempah dan Obat. 21 (2). $192-205$.

Isabela A. 2009. Pengaruh Ekstrak Lidah Buaya (Aloe vera) terhadap Pertumbuhan Pseudomonas aeruginosa pada Penderita Osteomielitis Bangsal Cempaka Rumah Sakit Ortopedi Prof.Dr.R.Soeharso Surakarta In Vitro [Abstrak]. Solo (ID): UPT Perpustakaan Universitas Sebelas Maret.

Lazzarini R, Duarte I, Ferreira AL. 2013. Patch Tests. Anais Brasileiros De Dermatologia. 88(6):879-888

Pradipto M. 2009. Pemanfaatan Minyak Jarak Pagar (Jatropa curcas L) Sebagai Bahan Dasar Sabun Mandi. Bogor (ID): Fakultas Teknologi Pertanian Institut Pertanian Bogor. Hal: 16;22.

Purbaya JR. 2003. Mengenal dan Memanfaatkan Khasiat Aloe vera. Bandung (ID): cv Pionerjaya. Hal 21-165.

Rahayu ID. 2006. Aloe barbadensis Miller dan Aloe chinensis Baker sebagai Antibiotik dalam Pengobatan Etnoveteriner Unggas secara In Vitro. Jurnal Protein. 13(1).

Sari R, Ferdinan A. 2018. Pengujian Aktivitas Antibakteri Sabun Cair dari Ekstrak Kulit Daun Lidah Buaya. Pharmaceutical Sciences and Research. 4(3), pp.111-120.
Srivasta SB. 1982. Soap, Detergent and Parfume and Industry (Soap and Detergent Manufacturing Guide). $43^{\text {rd }}$ Publication On Small Scale Industries. New Delhi (IN): Small Industry Research Institute.

Standar Nasional Indonesia 06-3532-1994. Sabun Mandi. Jakarta: Dewan Standarisasi Nasional. Hal 110

Standar Nasional Indonesia. 06-4085-1996. Sabun Mandi Cair. Jakarta (ID): Dewan Standarisasi Nasional. Hal 1-10.

Schmitt WH. 1996. Skin Care Products. London : Blackie Academe and Professional.

Sunsmart. 1998. Anatomy of The Skin, J. Cosmetics and Toiletries. New York (USA): SunSmart Inc.

Tanno LK, Darlenski R, Sánchez-Garcia, S, Bonini $M$, Vereda A, Kolkhir P, Antolin-Amerigo D, Dimov V, Gallego-Corella C, Becerra JCA, Diaz A. 2016. International survey on skin patch test procedures, attitudes and interpretation. World Allergy Organization Journal. 9(1), p.8.

Wasitaatmadja SM. 1997. Penuntun Ilmu Kosmetik Medik. Jakarta(UI): UI-Press.

Wilkinson DS, Fregert S, Magnusson B, Bandmann HJ, Calnan CD, Cronin E, et al. 1970. Terminology of contact dermatitis. Acta Dermato Venereologica. 50:287-292. 